\title{
Financial Reporting Quality in Private Equity Backed Companies: The Impact of Ownership Concentration
}

Christof Beuselinck*
Sophie Manigart

\begin{abstract}
We empirically show on a sample of 270 unquoted, private equity backed companies that the shareholder structure of private companies impacts the quality of their publicly available accounting information. More precisely, companies in which private equity (PE) investors have a high equity stake produce lower quality accounting information than companies in which PE investors have a low equity stake, after controlling for factors like company size and age. We explain our findings by arguing that PE investors with low equity stakes have a higher need for high quality accounting information whereas PE investors with high equity stakes have other means to closely monitor their portfolio companies.
\end{abstract}

KEY WORDS: financial reporting quality; governance; ownership structure; private equity.

JEL CLASSIFICATIONS: G34; L26; M13; M41.

Final version accepted on 102006.

*This paper has benefited from discussions with workshop participants at the Max Planck Institute. We specifically want to thank Lorraine Uhlaner and Mike Wright (guest editors), two anonymous referees as well as Ignace De Beelde, Wouter De Maeseneire, Marc Deloof, Miguel Meuleman and Lloyd Steier for helpful suggestions. Part of this research was completed when Christof Beuselinck was an FWO Scholar at Ghent University. Financial support from the Fonds of Wetenschappelijk Onderzoek (Grant G.0012.02) is kindly appreciated. The usual disclaimer applies.

Christof Beuselinck

Department of Accountancy

Tilburg University

Warandelaan 2, PO box 90153 Tilburg, 5000 LE

Netherlands

E-mail: C.Beuselinck@uvt.nl

Sophie Manigart

Department of Accounting \& Corporate Finance

Ghent University and Vlerick Leuven-Ghent

Management School

Kuiperskaai 55E, 9000 Gent

Belgium

\section{Introduction}

It is well documented that getting private equity ${ }^{1}$ (PE) has a profound impact on the way entrepreneurial companies operate. PE investors are active financial intermediaries, which operate in an environment characterized by extensive information asymmetries, leading to high adverse selection and moral hazard risks (Bottazzi et al., 2004; Brander et al., 2002). Further, the illiquidity and non-diversifiability of PE firms' investments create high idiosyncratic and market risks. As a consequence, PE investors are active financial intermediaries, allowing them to reduce these risks. As such, they fulfill two distinct roles: one of monitoring the progress of the portfolio company and one of supporting the portfolio company, thereby affecting the corporate governance systems in-place (Cowling, 2003; Kaplan and Stromberg, 2004) and creating value (Manigart and Sapienza, 1999).

In this paper we highlight the impact of PE investor governance on one specific aspect of the functioning and professionalization of their portfolio companies. More specifically, we explore the relationship between the ownership stake of a PE investor and the quality of the accounting information made public by its portfolio company, hereby extending the finding that PE investors positively affect the accounting information dissemination of their portfolio companies (Beuselinck et al., 2004; Davila and Foster, 2005; Katz, 2006). We provide evidence that the extent of PE ownership in a company significantly influences the quality of its financial accounts. We explain this finding from basic economic theory, where high financial reporting quality is a natural outcome of PE monitoring and governance but also depends on the proportional ownership of PE investors. 
This is an important research theme as various stakeholders such as banks, credit rating agencies, employees, customers and suppliers all rely partly on publicly available accounting information for their decision-making. By improving the quality of the accounting information in their portfolio companies, PE investors thus not only serve their own interests but they provide valuable services for other stakeholders as well. This might partially explain why $\mathrm{PE}$ investors have a positive certifying effect on their portfolio companies beyond the mere provision of financing (Gompers and Lerner, 1999). Despite the economic importance of this topic, only a few studies have so far looked at the properties and value relevance of financial reporting in PE backed firms (Armstrong et al., 2006; Beuselinck et al., 2004; Hand, 2005). The present paper adds to this stream of research by acknowledging that not only the mere fact of having a PE investor as shareholder influences the quality of the accounting information, but that also the importance of its ownership stake matters.

The entrepreneur - PE investor relationship almost inevitably results in the need for intensive monitoring by the investor and tight governance structures. Since both parties are interrelated by a principal - agent relationship where personal incentives of the agent (entrepreneur) may diverge from those of the principal (PE investor), $\mathrm{PE}$ investors typically try to solve the agency problem via contracts and intensive monitoring of the entrepreneurial activities (Kaplan and Strömberg, 2004). The European Venture Capital and Private Equity Association (EVCA) Book of Guidelines (chapter 4, p. 40) states that "monitoring should allow the [investment] manager to confirm that the investment is progressing in accordance with the relevant business plan and should provide sufficient information to identify any failures to meet targets or milestones and to formulate remedial plans where necessary." Monitoring often takes place through PE representatives in the board of directors where the progress of the venture is regularly assessed (Kaplan and Strömberg, 2001). In addition, PE investors have informal contacts with the entrepreneur and key managers (Sapienza et al., 1996) and they require structured interim information between board meetings (Beuselinck et al., 2006). Finally, they accelerate the introduction of a professionally developed, controllable financial reporting and internal control system in their portfolio companies (Davila and Foster, 2005; Mitchell et al., 1995).

Next to monitoring their portfolio companies, PE investors contribute to their progress in various ways: they give strategic, business and financial advice (Sapienza et al., 1996), they are instrumental in the recruitment of top management team members (Hellmann and Puri, 2002), and they act as a source of professional and industry contacts (Sapienza et al., 1996).

Although our understanding of the monitoring and value adding role of PE investors is increasing rapidly, the way these actions affect the corporate governance practices of their portfolio firms still remains largely unexplored. Moreover, there is hardly any evidence whether and how this change in corporate governance practices affects corporate decision-making and information disclosure of PE portfolio firms. A recent stream of research tackles this important research question by analyzing the interaction between PE presence and the reliability and value-relevance of financial statements. Hand (2005) illustrates that PE presence positively impact the value relevance of financial statements of PE-backed companies, especially when they are more mature. Beuselinck et al. (2004) document that the publicly reported financial information of unlisted Belgian PE backed firms is of a higher quality than that of similar non-PE backed firms. Katz (2006) finds similar results for a sample of unlisted PE backed US firms with proportions of public debt. The positive impact of PE investors on the quality of the financial reporting of their portfolio companies is explained by the active monitoring and governance efforts of PE investors and the ensuing professionalization of their portfolio firms.

This paper contributes to the novel literature on the interaction between PE ownership and the quality of external financial reporting in unquoted companies. More specifically, we examine the relation between PE share ownership and the quality of the financial reporting of their portfolio companies. We argue and 
empirically show on a sample of 270 unquoted $\mathrm{PE}$ backed Belgian companies that the quality of the publicly reported accounting information of entrepreneurial companies depends on the equity percentage held by the PE investor. ${ }^{2} \mathrm{We}$ document that the quality of the accounting information is highest when the PE investor has a low equity stake and that the information quality decreases when the equity stake of the PE investor is high. ${ }^{3}$ Our findings can be explained from basic agency theory (e.g. Jensen and Meckling, 1976) where high equity stakes correspond to high levels of control, which may substitute for the need for high quality financial information. PE investors with low shareholder percentages have less contractual decision and control rights in their portfolio companies. They therefore have to monitor the portfolio company more closely and rely to a larger extent on financial accounting information, hereby essentially improving the quality of the accounting information of their portfolio companies even more than PE investors with larger equity stakes and with other control mechanisms at their disposal.

We measure earnings quality in a conventional way and focus on two of its vital attributes: the extent of earnings management and the timeliness of loss reporting (see e.g. Leuz et al., 2003 or Ball and Shivakumar, 2005). We define earnings management as the intentional modification of a firm's performance by insiders to either mislead stakeholders or to influence contract terms. In general, more earnings management is associated with lower quality financial information (Leuz et al., 2003). Timeliness of loss reporting is a measure of the conservatism of the reported earnings. Reporting losses in a timely manner, rather than spreading the losses over future periods, is an alternative indicator of earnings quality (Francis et al., 2005).

Our findings are important as different types of stakeholders rely to a large extent on publicly reported accounting information provided by private companies. Accounting information is important for banks in making credit decisions and in monitoring companies. The accounting information that Belgian SMEs have to report publicly is commonly used by banks to assess the financial health of a company. It is equally important for employees, suppliers and customers as these stakeholders are interested in the financial health of the focal company and hence in the reliability and quality of the reported information. Further, (minority) shareholders receive dividends based on a firm's reported profitability and new vendor contracts partially depend on a firm's financial stability. Finally, commercial credit information companies, such as Dun \& Bradstreet (www.dnb.com) or Graydon (www.graydon.be), rely to a large extent on public accounting information of SMEs to assign their credit ratings. In summary, our findings suggest that stakeholders, interested in external accounting information, should take into account the shareholder structure of the company in order to correctly interpret the accounting information. More precisely, external stakeholders should not only consider PE presence, but also their proportional share ownership, when assessing the quality of the reported financial accounting information.

The remainder of this paper is as follows. Section 2 discusses the motivation and theory underlying the hypotheses, while section 3 describes the data collection procedure and sample characteristics. In section 4 , we extend on the empirical models employed to study financial reporting quality and section 5 presents the results. Finally, we conclude and discuss implications for future research in section 6 .

\section{Theory development}

The quality of publicly reported financial information of companies is important in our economic society as numerous stakeholders make decisions based on this information and therefore to a large extent depend on its accuracy. Not surprisingly, a large stream of literature examines the quality of a firm's publicly reported financial information (e.g. Francis et al., 2005; Leuz et al., 2003; Ball and Shivakumar, 2005).

Although most studies on earnings quality focus on publicly listed companies, there is recent evidence that the quality of reported earnings of private companies is lower than that of listed companies (Ball and Shivakumar, 2005). This is explained by the observation that 
private companies face a lower demand for producing high quality information, as they do not have to report to external shareholders and are not followed by financial analysts (Ball and Shivakumar, 2005). However, recent evidence suggests that PE governance positively affects accounting information production, both internally (Kaplan and Strömberg, 2004; Davila and Foster, 2005) and externally (Beuselinck et al., 2004; Katz, 2006). Beuselinck et al. (2004) have shown that the reporting quality is higher for unlisted PE-backed companies than for comparable companies that did not receive PE. Katz (2006) finds similar results for US PE backed unlisted firms with proportions of public debt. This can be explained by the fact that PE investors have strong incentives to closely monitor the performance of their portfolio companies in order to minimize potential moral hazard problems between entrepreneurs and investors (Sapienza and Korsgaard, 1996; Cornelli and Yosha, 2003). This intensive monitoring results in a higher quality of the publicly reported financial information.

An unexplored but potentially important determinant of a portfolio firm's financial reporting quality is the proportional equity stake that a PE investor has in that firm. Both analytical and empirical studies suggest that the governance and control of a portfolio company not only depends on the contracted control and decision rights between PE investors and the entrepreneur, but also on the equity stake that a $\mathrm{PE}$ investor holds in the venture (e.g. Aghion and Bolton, 1992; Kaplan and Strömberg, 2004). Hence, although enhanced monitoring by $\mathrm{PE}$ investors does improve financial reporting quality of the portfolio firm on average (Beuselinck et al., 2004; Katz, 2006), the importance of the effect may depend on the equity stake of the PE investor.

Agency theory (Jensen and Meckling, 1976) provides a framework for linking the quality of accounting information to the proportional equity stake of PE investors. Multiple studies show that $\mathrm{PE}$ investors introduce corporate governance mechanisms to solve agency problems and to ensure that entrepreneurs act in the common interest (e.g. Gompers and Lerner, 1999; Kaplan and Strömberg, 2004). If a PE company has a high proportional equity stake in the firm, it has a determining voice in the company's board and therefore is expected to have a good insight in the real evolution and economic performance of the firm without having to rely on publicly reported financial information. ${ }^{4}$ If, by contrast, a PE company only has a small proportion of the total share capital, it has less voting power and control in the firm. To the extent that contracted decision and control rights do not compensate this low proportional ownership, PE investors with a low equity stake in portfolio firms will therefore feel the need to monitor the entrepreneurial activities more closely since the entrepreneur has more possibilities to mask the true firm performance.

This is particularly relevant given the nature of the contracts between the PE investors and the entrepreneurial companies. Entrepreneurs have incentives to manipulate the short-term performance of the venture, especially when the venture is performing poorly, despite the negative effect of these actions on the mutual trust when detected (Sapienza and Korsgaard, 1996; Cornelli and Yosha, 2003). When predefined milestones are not met, PE investors often have the option to acquire more control in the company (Kaplan and Strömberg, 2004) or to abandon the venture by denying further financing (Cornelli and Yosha, 2003). As a result, the incentive of $\mathrm{PE}$ investors to monitor the financial reporting process closely is particularly high when they have a small proportional equity stake in the venture. Since a portfolio firm's performance is reflected in its financial reporting and since this is subject to manipulation when not monitored closely, PE investors with low equity stakes have a higher incentive to ensure that the accountability of the firm's financial reports is high.

While PE investors especially focus on the quality of the internally reported information (Mitchell et al., 1995; Kaplan and Strömberg, 2004), we argue that the improved quality of internal information equally leads to improved quality of externally presented accounting information. While presenting two sets of performance figures - one for internal use and one for external use - is common practice in large companies, this practice induces higher 
accounting and audit costs which may be excessive for small, private companies (Ball and Shivakumar, 2005). Hence, high-quality internal reporting figures are also expected to result in a high quality of the publicly reported figures for smaller, unquoted companies. As a result, we conjecture that the higher discipline in financial reporting required by $\mathrm{PE}$ investors with low equity stakes results in higher quality of the publicly available financial information. Hence:

P1: The quality of the reported earnings of a $P E$ backed company is inversely related to the equity percentage a PE investor holds.

There are, however, arguments that suggest that a higher PE ownership share might lead to higher financial reporting quality in the portfolio company. For instance, PE portfolio firms typically have a high demand for additional external financing, as they are growth oriented, or are operating with negative cash flows. The initial PE investment is often not sufficient to cover the external financing needs of most portfolio companies. Therefore, after having received PE, PE backed companies frequently issue significant amounts of additional equity or bank debt. When issuing equity, they may either raise funding from the initial PE investors or they may invite new shareholders (Baeyens and Manigart, 2005). Recent studies have shown that, in the long run, quoted companies are able to attract more financing at better terms, leading to lower cost of capital and enhanced value, when the quality of the reported earnings is higher (Bharat et al., 2004; Francis et al., 2005). Therefore, PE investors might want to push for high quality in portfolio firm's accounting information. As a result, given that PE investors have more influence when holding larger equity stakes, a higher equity stake of the PE investor could correspond to higher quality accounting information of the portfolio company.

Another determinant potentially leading to a positive association between PE share ownership and financial reporting quality is that PE investors are concerned about their reputation in the market (Gompers and Lerner, 1999). Having a good reputation is often associated with having higher quality deal flow, increasing the odds to be invited to syndicated deals, and being able to raise follow-on funds at favorable terms. The reputation of a PE investor depends on the quality of its deals and consequently also on the quality of its portfolio firms. As a result, pursuing a high quality level in the financial reporting of portfolio firms is one potential instrument for PE investors to signal their good reputation. Pursuing high quality levels in the publicly available financial reporting of their portfolio companies might thus be an objective in itself. Again, since PE investors that hold large equity stakes typically have more influence and control in their portfolio firms, this argument suggests a positive association between PE share ownership and financial reporting quality. Consequently, foregoing arguments lead to:

P2: The quality of the reported earnings of a $P E$ backed company is positively related to the equity percentage a PE investor holds.

\section{Data}

The foregoing propositions are tested on a unique hand-collected dataset with financial and non-financial data of 270 unquoted Belgian PE backed companies, covering the period 19851999. We focus on Belgian companies, as all Belgian companies are required by law to make their yearly financial statements public, enabling us to study the relation between publicly available financial reporting quality and PE governance in their unlisted portfolio companies. ${ }^{5}$ Companies that received $\mathrm{PE}$ are identified through annual reports of PE investors, investment reports and press releases. We exclude financial services companies, as their financial statements are different from those of industrial or service companies. As the accounting information of start-ups is often incomplete, we include only firms that were at least two years old when they first received PE. ${ }^{6}$

Financial statements of the sample firms are supplied by the National Bank of Belgium and retrieved from Belfirst $^{\odot}$, a financial database from Bureau Van Dijk. The yearly financial statements from the investment year up to maximally 10 years after the investment are used in the analyses. A firm is removed from the dataset from the moment 
that a structural change in its legal status occurs, which would make it impossible to interpret the financial statements correctly. A change may either be a merger or acquisition with another firm or a bankruptcy filing. Additionally, we require that the firm does not obtain a public listing status during our observation period as this event might bias the quality of its financial reporting. On average, we have seven consecutive years of financial statements available for each firm, with a minimum of three and a maximum of ten years. This results in a total of 1,890 valid firm-year observations from the 270 sample firms. Next to the financial statement information, we collect the equity stake initially held by the PE investor from investment reports and financial statements. We consider the equity stake of the lead investor when more than one PE investor invested in the company in the initial investment round.

Table I shows the characteristics of the 270 sample firms. Panel A shows the frequency distribution of the equity stake of the lead investor. The average equity percentage held by $\mathrm{PE}$ investors varies widely with a minimum of $5.7 \%$ and a maximum of $82.8 \%$. PE investors hold less than $20 \%$ of the shares in almost one in four of the portfolio companies, less than $28 \%$ in half of the companies, and less than $40 \%$ in three quarters of the companies. PE investors hold a majority stake of $50 \%$ or more in only $1.9 \%$ of the sample firms.

Panel B of Table I shows the age distribution of the portfolio companies at the time they received their first PE investment, being the age since the creation of the company. A substantial number of firms are relatively young. $10 \%$ of the sample firms are only two years old when they first received PE; about half of the sample firms are less than five years old and about $60 \%$ are younger than seven years when they receive their first PE investment. The variation in age is large, as almost $30 \%$ of the firms in the sample are more than 10 years old when receiving PE. This shows that our sample spans early stage (but not start-ups), later stage and expansion companies. The stage of development of the company is captured by the age variable.

With respect to industry classification (measured by one-digit NACE classification and reported in Table I, panel C), most sample firms
TABLE I

Characteristics of sample companies $(\mathrm{N}=270)$

Panel A: Frequencies of ownership percentage of the lead $\mathrm{PE}$ investor

\begin{tabular}{lll}
\hline Ownership \% & $\begin{array}{l}\text { Percentage of } \\
\text { sample firms }\end{array}$ & $\begin{array}{l}\text { Cumulative } \\
\text { percentage } \\
\text { of sample firms }\end{array}$
\end{tabular}

Minimum $=5.7$

$5.7 \%<X<10 \%$

$10 \%<X<20 \%$

6.8

6.8

$20 \%<X<25 \%$

17.9

24.7

$25 \%<X<30 \%$

20.1

$30 \%<X<40 \%$

16.1

15.0

22.2

$40 \%<X<50 \%$

1.2

$50 \%<X<60 \%$

$>60 \%$

0.7

44.8

60.9

75.9

98.1

99.3

Maximum $=82.8$

100.0

Panel B: Age of the portfolio company at initial PE investment

\begin{tabular}{lll}
\hline AGE in years & $\begin{array}{l}\text { Percentage of } \\
\text { sample firms }\end{array}$ & $\begin{array}{l}\text { Cumulative } \\
\text { percentage } \\
\text { of sample firms }\end{array}$ \\
\hline 2 & 10.0 & 10.0 \\
$2<X<3$ & 25.2 & 35.2 \\
$3<X<4$ & 10.5 & 45.7 \\
$4<X<5$ & 6.7 & 52.4 \\
$5<X<7$ & 8.2 & 60.6 \\
$7<X<10$ & 11.2 & 71.8 \\
More than 10 & 29.2 & 100.0
\end{tabular}

Panel C: Industry concentration of portfolio companies (Top 3 broad sector definitions)

\begin{tabular}{lll}
\hline Industry & $\mathrm{N}$ & Percentage \\
\hline $\begin{array}{l}\text { Metal manufacture } \\
\text { and electronic devices }\end{array}$ & 57 & 21.2 \\
$\begin{array}{l}\text { Business services } \\
\begin{array}{l}\text { Distribution, trade } \\
\text { and retail }\end{array}\end{array}$ & 46 & 17.1 \\
\hline
\end{tabular}

Note: Panel A of Table 1 reports frequencies of ownership percentages of the lead PE investor, obtained at the initial PE financing round. Panel B reports distributional properties of the age of all sample firms at the moment of the initial PE financing date. Panel $\mathrm{C}$ lists the top 3 sectors represented in our sample PE backed firms.

are active in Manufacturing and Electronic Devices $(21 \%)$, in Business Services $(17 \%)$ and in Distribution, Trade and Retail (17\%).

For the purpose of our analyses, we split the sample into companies in which the PE investor holds relatively low equity stakes (defined as less 
than $40 \%$ ) and those in which the PE investor holds relatively high equity stakes (more than $40 \%$ ). This corresponds to comparing the subset of firms in the highest PE ownership quartile to all other PE backed firms and results in 1,435 (75\%) company-years with low equity stakes and $455(25 \%)$ company-years with high equity stakes. We did sensitivity analyses with other cut-off values for low and high equity stakes, which did not alter the results. The dummy variable Highperc takes a value of 1 if the PE investor holds more than $40 \%$ of the shares and 0 if the investor holds less than $40 \%$ of the shares.

Table II shows the variables used in the multivariate analyses, for both groups of low equity percentage and high equity percentage firms. Firms in which PE investors have a high ownership percentage are significantly smaller (with size measured as total assets) than low equity percentage firms, both with respect to mean and median values. This suggests that PE investors hold highest proportional equity ownership stakes in smaller firms in our sample. Low equity percentage firms are significantly older (mean of 14.8 years) than high equity percentage firms (mean of 13.4 years), although the difference is not substantial in real terms. The other variables are not significantly different between the two subsets of firms: EBIT, cash flow, change in profits before and after taxes and accounting accruals are comparable for low equity percentage and high equity percentage firms.

\section{Method of analysis}

Using correctly defined proxies for accounting quality is essential. We measure earnings quality through two of its vital attributes that are commonly used in financial accounting research: the extent of earnings management and the timeliness of loss reporting (e.g. Leuz et al., 2003; Francis et al., 2005; Ball and Shivakumar, 2005). In this section, we briefly explain the characteristics and interpretation of these measures.

\subsection{Tests of earnings management}

Consistent with earlier research, we define earnings management as the intentional modi- fication of a firm's performance by insiders to either mislead stakeholders or to influence contract terms. Mainstream accounting research measures the extent of earnings management through the accruals components in a company's financial statements. Accruals are accounting elements that distinguish a firm's cash flow from operations from its reported earnings. Part of these accruals follow inherently from the growth of business activities, but managers have some flexibility in reporting accruals so as to influence the bottom line reported earnings (Leuz et al., 2003). Accounting research generally considers accruals related to working capital and depreciation policy. By definition, accruals are computed as follows:

$$
\begin{aligned}
\text { Accruals }= & \Delta(\text { Accounts Receivable }+ \text { Inventory } \\
& + \text { Other Current Assets }) \\
& -\Delta(\text { Accounts Payable } \\
& + \text { Other Current Liabilities }) \\
& - \text { Depreciation }
\end{aligned}
$$

The basic role of accruals is to construct an earnings measure that is less noisy over time than the realized cash flow is. As a result, earnings figures should be more closely related to the real underlying firm performance than cash flow figures are (Dechow, 1994; Ball and Shivakumar, 2005). Hence, it is clear that accruals and cash flow are both contemporaneously and serially negatively correlated over time. However, larger magnitudes of this correlation do not necessarily reflect a firm's underlying economic performance and are considered to be a signal of earnings management (Leuz et al., 2003). We therefore test the intrinsic relation between accruals and cash flow and differentiate our analyses for high versus low equity ownership percentages. This results in the following model:

$$
\begin{aligned}
\mathrm{ACC}_{i, t}= & \alpha_{i, t}+\beta_{1} \mathrm{OCF}_{i, t}+\beta_{2} \text { Highperc }_{i} \\
& +\beta_{3} \text { Highperc }_{i} \times \mathrm{OCF}_{i, t} \\
& +\beta_{4} \log (\text { Total Assets })_{i, t} \\
& +\beta_{5} \log (\text { Age })_{i, t}+\Theta^{\prime} \mathrm{IND}_{i}+\varepsilon_{i, t}
\end{aligned}
$$

with $i=$ a firm indicator and $t=$ a time indicator, Acc $=$ total accruals, defined as above, 


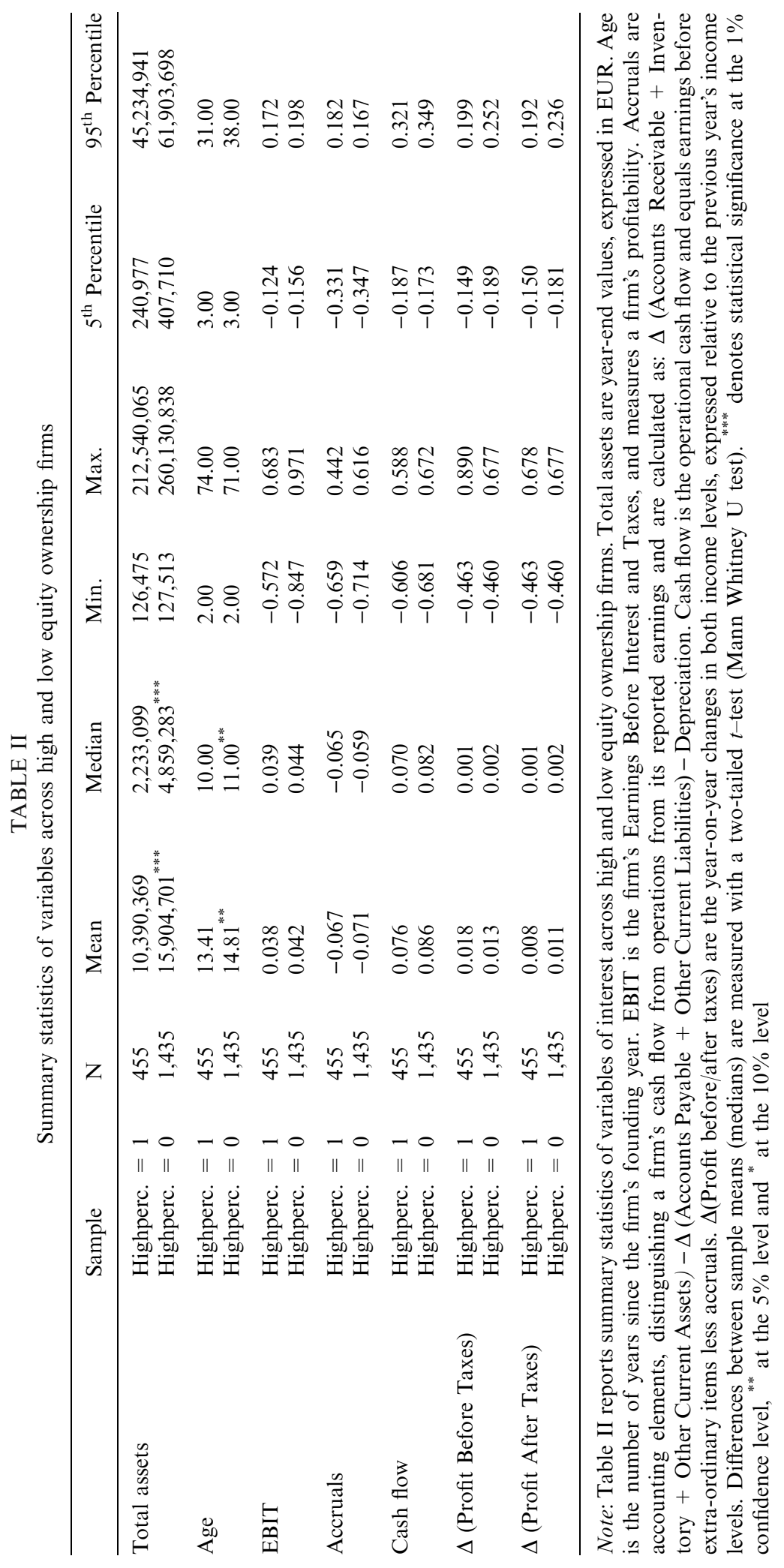


Highperc (dummy variable) $=1$ if $\mathrm{PE}$ investors have equity stake higher than cut-off level, 0 otherwise, $\mathrm{OCF}=$ operational cash flow, $\ln$ (TotalAssets) $=$ natural logarithm of total assets, $\ln ($ Age $)=$ natural logarithm of the firms' age, IND = industry dummies (one-digit sector codes).

Because of the intrinsic negative relation between total accounting accruals and operational cash flow, we expect $\beta_{1}$ to be negative. Next to the OCF variable, we include the Highperc dummy (coefficient $\beta_{2}$ ) and the interaction between the Highperc dummy and OCF (coefficient $\beta_{3}$ ). A significant coefficient for $\beta_{3}$ indicates that there is a difference in the earnings management behavior of high and low equity ownership firms. A significantly negative coefficient of the interaction term $\beta_{2}$ supports Proposition 1 (i.e. firms in which PE investors have a high equity stake report lower quality financial reporting compared to low equity firms). By contrast, a significantly positive coefficient would provide support for the alternative Proposition 2 that high PE equity stakes correspond with higher quality financial reporting.

Total assets and age are included as control variables, as the bivariate analyses have shown that companies in which PE investors have a high equity stake are typically smaller and younger. Finally, IND controls for industry fixed effects (measured as one-digit sector codes).

\subsection{Tests of timely loss recognition}

The second proxy for earnings quality, namely the timeliness of loss reporting, is a measure of the conservatism of the reported earnings. Reporting losses in a timely manner, rather than spreading the losses over future periods, leads to more conservative earnings (Ball and Shivakumar, 2005). It is an indicator of earnings quality, since conservative financial statements are more reliable for creditors, shareholders, managers and other external parties to assess the proper value of the company (Watts, 2003). Following the Ball and Shivakumar model (2005), earnings are of a higher quality if bad news is reported as a transitory shock (i.e. a one-time dip) in current earnings. We measure timely loss reporting in accounting income by focusing on the tendency for income decreases to reverse. If prior-period earnings decreases show a higher tendency to reverse than prior-period earnings increases, this is evidence of a higher willingness to recognize losses timely and corresponds to higher earnings conservatism. Transitory gain and loss components are estimated as follows (Ball and Shivakumar, 2005):

$$
\begin{aligned}
\Delta \mathrm{NI}_{t}= & \beta_{0}+\beta_{1} \mathrm{NEG}(\Delta \mathrm{NI})_{t-1}+\beta_{2} \Delta \mathrm{NI}_{t-1} \\
& +\beta_{3} \operatorname{NEG}(\Delta \mathrm{NI})_{t-1} * \Delta \mathrm{NI}_{t-1}+\varepsilon_{t},
\end{aligned}
$$

with: $\Delta \mathrm{NI}_{t}=$ income change at time $t$, scaled by beginning-of-the-year book value of total assets, $\Delta \mathrm{NI}_{t-1}=$ income change at time $t-1$, scaled by beginning-of-the-year book value of total assets, $\operatorname{NEG}(\Delta \mathrm{NI})_{t-1}=$ dummy variable taking the value of 1 when prior-period earnings changes are negative.

By making the estimation model dependent on prior period earnings decreases, we are able to study the reversion tendency of losses and gains separately. If losses are recognized in a timely manner, then the coefficient $\left(\beta_{2}+\beta_{3}\right)$ will be negative. Further, losses are recognized in a more timely way than gains if $\beta_{3}<0$. To test the relationship between the equity percentage of the PE investor and timely loss recognition, we supplement model (3) with the Highperc (here denoted as: HEP) dummy. This results in the model (4):

$$
\begin{aligned}
\Delta \mathrm{NI}_{t}= & \alpha_{0}+\beta_{1} \mathrm{NEG}(\Delta \mathrm{NI})_{t-1}+\beta_{2} \Delta \mathrm{NI}_{t-1} \\
& +\beta_{3} \mathrm{NEG}(\Delta \mathrm{NI})_{t-1} * \Delta \mathrm{NI}_{t-1} \\
& +\beta_{4} \mathrm{HEP}+\beta_{5} \mathrm{HEP} * \mathrm{NEG}(\Delta \mathrm{NI})_{t-1} \\
& +\beta_{6} \mathrm{HEP} * \Delta \mathrm{NI}_{t-1}+\beta_{7} \mathrm{HEP} \\
& * \mathrm{NEG}(\Delta \mathrm{NI})_{t-1} * \Delta \mathrm{NI}_{t-1}+\varepsilon_{t}
\end{aligned}
$$

with: $\Delta \mathrm{NI}_{t}=$ income level change at time $t$, scaled by beginning-of-the-year total assets, $\Delta \mathrm{NI}_{t-1}=$ income level change at time $t-1$, scaled by beginning-of-the-year total assets, $\operatorname{NEG}(\Delta \mathrm{NI})_{t-1}=$ dummy for prior-period negative income level change, HEP = dummy variable $=1$ if $\mathrm{PE}$ investors have equity stake higher than cut-off level, 0 otherwise.

We are interested in differences in timely loss reporting between companies in which $\mathrm{PE}$ 
investors hold high equity percentages and those in which PE investors hold low equity stakes. Therefore, our discussion will primarily focus on $\left(\beta_{6}+\beta_{7}\right)$ as this measures the compound effect for differences in timely loss reporting between both subsamples. If $\left(\beta_{6}+\beta_{7}\right)>0$, then Highperc companies recognize losses less timely compared to firms where PE ownership shares are lower, and vice versa. Hence, finding a significantly positive coefficient for $\left(\beta_{6}+\beta_{7}\right)$ suggests lower accounting quality in Highperc firms and supports Proposition 1. By contrast, observing a significantly negative coefficient is consistent with Proposition 2. ${ }^{7}$

\section{Multivariate findings}

Table III reports the accruals - cash flow models. Regression (1) models the accruals as a function of the operational cash flow and the size and age control variables. In regression (2), we condition for high versus low equity percentage firms, without taking the control variables into account. Regression (3) is the full model and is similar to regression (2) but additionally incorporates the control variables for size and age. All models are highly significant.

Table III confirms that accounting accruals and cash flows are negatively correlated. This is consistent with general findings in the accounting literature (e.g. Dechow, 1994; Ball and Shivakumar, 2005). The coefficient of the interaction term Highperc $\times \mathrm{OCF}\left(\beta_{3}\right)$, which is the coefficient of interest for our propositions, is significant and negative in all regressions. ${ }^{8}$ This supports Proposition 1: accruals of companies in which PE investors hold large equity stakes are more negatively related to the operational cash flows than those of companies in which PE investors hold small equity stakes. In other words: accounting quality, measured by its earnings management component, is lower in firms where PE investors hold high equity stakes compared to those where PE investors hold low equity stakes. Further, the coefficients of the control variables (age and size) are significant and positive.

Table IV reports the timeliness of loss reporting models. We focus on profit before taxes (regressions (1) and (2)) and profit after taxes (regressions (3) and (4)). ${ }^{9}$ The first and third columns show the estimation results of the base model (3), while the second and fourth columns show the estimation results of the full model (4) including the Highperc variables. All models are significant; adding the Highperc variables improves the fit of the models.

The coefficient of $D(\Delta \mathrm{NI})_{t-1} \times \Delta \mathrm{NI}_{t-1}\left(\beta_{3}\right)$ is significant and negative in Regressions (1) and (3). This indicates that losses are recognized more timely than gains by all firms in the sample. Further, $\left(\beta_{2}+\beta_{3}\right)$ is significant and negative in Regressions (1) and (3), strengthening the finding of timely recognition of losses. When adding the Highperc dummy variable and interaction terms in Regressions (2) and (4), $\beta_{7}$ is significantly positive. This implies that high equity percentage companies recognize losses less timely than gains, compared to low equity percentage companies. Moreover, $\left(\beta_{6}+\beta_{7}\right)$ is significantly positive, suggesting that Highperc firms report losses less timely compared to other PE backed firms. Results hold and are significant for both profit before and after taxes: $\left(\beta_{6}+\beta_{7}\right)$ equals $0.055(t=1.98)$ for profit before taxes and $0.093(t=2.23)$ for profit after taxes. ${ }^{10}$

Hence, the results with respect to the timeliness of loss recognition also provide support for Proposition 1: companies in which PE investors hold a large equity stake recognize losses less timely than those in which PE investors hold a small equity stake. Recognizing losses in a less timely fashion corresponds to a lower quality and reliability of financial reporting. In summary, both attributes of earnings quality, namely the extent of earnings management and the timeliness of loss reporting, yield consistent results and both support Proposition 1.

\section{Conclusion and discussion}

The governance and shareholder structure of an unquoted company determines how that company functions (Cowling, 2003). We have provided evidence on how PE shareholders influence one aspect of the professionalization of a company, namely the quality of its financial accounts provided to the public community. While previous research has shown that the quality of the financial accounts of an unquoted 
TABLE III

Multivariate OLS regressions : accruals - cash flow relation

\begin{tabular}{llll}
\hline Dependent variable: accruals & Regression $(1)$ & Regression $(2)$ & Regression (3) \\
\hline Intercept & $-0.144^{* * *}(-3.85)$ & $-0.038^{* * *}(1.47)$ & $-0.145^{* * *}(-3.83)$ \\
OCF & $-0.691^{* * *}(-43.07)$ & $-0.662^{* * *}(-36.20)$ & $-0.669^{* * *}(-37.08)$ \\
Highperc & $/$ & $0.001(0.92)$ & $0.007(1.04)$ \\
Highperc $\times$ OCF & $/$ & $-0.099^{* * *}(-2.51)$ & $-0.105^{* *}(-2.65)$ \\
Log(Total assets) & $0.005^{* *}(3.06)$ & $/$ & $0.005^{* * *}(3.02)$ \\
Log(Age) & $0.019^{* * *}(5.32)$ & $/$ & $0.019^{* * *}(5.36)$ \\
Sector dummies & Included & Included & Included \\
Adjusted $R^{2}$ & 0.506 & 0.493 & 0.508 \\
$F$-statistic & 174.67 & 166.17 & 148.77 \\
Sample size & 1,890 & 1,890 & 1,890 \\
\hline
\end{tabular}

Note: Table III reports regression results of operating cash flow on accruals levels across all sample firm-years. Highperc is a dummy variable equal to one if the PE investor owns more than the predefined cut-off point $(40 \%)$ of the outstanding share capital. (Highperc $\times$ OCF) is the interaction variable of the Highperc dummy and the operating cash flow and measures the incremental association between accruals and cash flows for firms with high PE investor ownership stakes. Regression (1) tests for the relation between accruals and operating cash flow (OCF) without conditioning the sample for high and low equity percentage firms. Regression (2) tests for differences in the accruals - cash flow relation between high and low equity percentage firms and Regression (3) additionally controls for Size and Age. Results are consistent (but not reported for the sake of brevity) for sensitivity adjustments in the choice of the cut-off point for high versus low equity percentages. ${ }^{* * * *}$ statistically significant at the $1 \%$ confidence level, ${ }^{* *}$ at the $5 \%$ level and ${ }^{*}$ at the $10 \%$ level.

company significantly improves when a PE investor becomes a shareholder, our study provides evidence that the equity percentage held by the PE investor has a moderating impact on the quality of the financial accounts. The quality of publicly available financial information is lower when the PE investor holds a large equity stake, while it is higher when the PE investor holds a small equity stake.

We interpret this as evidence that the quality of the financial accounts of an unquoted company and the proportional equity stake of external PE investors are substitutes rather than complements. Our findings are explained from basic agency theory and the importance of financial reporting in monitoring entrepreneurial actions. In portfolio firms where PE investors have only low proportional equity stakes, their decision power and insight in the true performance of the firm is low compared to the situation where PE investors have large proportional equity stakes. Since entrepreneurs have an incentive to manage the performance of the venture (Sapienza and Korsgaard, 1996; Cornelli and Yosha, 2003) and that this is reflected in financial reporting, PE investors with low share ownerships know the danger of un- monitored financial reporting and react by strongly disciplining the financial reporting and internal accounting control system. To the extent that publicly reported information is in line with internal reporting, this results in better external financial reporting quality for portfolio firms in which PE investors have low equity stakes, and vice versa.

This finding is important for external stakeholders for whom financial accounts of companies yield important input for their decisionmaking process. These include banks, suppliers, customers, employees and credit rating agencies, but also prospective later-round equity investors or acquirers. These parties all should realize that the quality of the reported financial performance is not to be taken at face value. Although the quality of the accounting figures of PE backed companies is, in general, better than that of comparable companies that are not backed by PE investors (Beuselinck et al., 2004; Katz, 2006), the equity percentage held by the lead PE investor is an additional important determinant of this relationship. This suggests that differences in proportional ownership concentration correspond to dissimilar governance focus with respect to monitoring of financial reporting, and 
TABLE IV

Multivariate OLS regressions: timeliness of loss reporting

\begin{tabular}{|c|c|c|c|c|c|}
\hline \multirow[t]{2}{*}{ Dependent variable: $\Delta$ (Net income) } & & \multicolumn{2}{|c|}{$\begin{array}{l}\text { Net income level = Profit before } \\
\text { taxes }\end{array}$} & \multicolumn{2}{|c|}{ Net income level $=$ Profit after taxes } \\
\hline & & Regression (1) & Regression (2) & Regression (3) & Regression (4) \\
\hline Intercept & & $0.022(0.48)$ & $0.021(0.44)$ & $0.027(0.60)$ & $0.028(0.59)$ \\
\hline $\mathrm{D}(\Delta \mathrm{NI})_{t-1}$ & $\left(\beta_{1}\right)$ & $-0.011(-1.46)$ & $-0.007(-0.84)$ & $-0.012(-1.67)$ & $-0.009(-1.16)$ \\
\hline$\Delta \mathrm{NI}_{t-1}$ & $\left(\beta_{2}\right)$ & $-0.063^{* *}(-2.31)$ & $-0.023(-0.73)$ & $-0.064^{* *}(-2.41)$ & $-0.023(-0.75)$ \\
\hline $\mathrm{D}(\Delta \mathrm{NI})_{t-1} \times \Delta \mathrm{NI}_{t-1}$ & $\left(\beta_{3}\right)$ & $-0.547^{* * *}(-9.75)$ & $-0.599^{* * * *}(-9.46)$ & $-0.582^{* * * *}(-10.59)$ & $-0.645^{* * *}(-10.39)$ \\
\hline Highperc. & $\left(\beta_{4}\right)$ & 1 & $0.016(1.35)$ & 1 & $0.013(1.13)$ \\
\hline Highperc. $x \mathrm{D}(\Delta \mathrm{NI})_{t-1}$ & $\left(\beta_{5}\right)$ & / & $-0.015(-0.91)$ & / & $-0.010(-0.61)$ \\
\hline Highperc. $\times \Delta \mathrm{NI}_{t-1}$ & $\left(\beta_{6}\right)$ & / & $-0.173^{* * *}(-2.76)$ & / & $-0.174^{* * * *}(-2.86)$ \\
\hline Highperc. $\times \mathrm{D}(\Delta \mathrm{NI})_{t-1} \times \Delta \mathrm{NI}_{t-1}$ & $\left(\beta_{7}\right)$ & / & $0.228^{*}(1.77)$ & / & $0.267^{*}(2.12)$ \\
\hline $\log ($ Total assets $)$ & $\left(\beta_{8}\right)$ & $-0.003(-0.09)$ & $-0.002(-1.29)$ & $-0.003(-1.38)$ & $-0.003(-1.29)$ \\
\hline $\log ($ Age $)$ & $\left(\beta_{9}\right)$ & $0.007(1.50)$ & $0.007(1.52)$ & $0.007(1.54)$ & $0.007(1.53)$ \\
\hline Sector dummies & & Included & Included & Included & Included \\
\hline Adjusted $R^{2}$ & & 0.097 & 0.107 & 0.109 & 0.111 \\
\hline$F$-statistic & & 16.65 & 13.22 & 18.77 & 14.92 \\
\hline Sample size & & 1,890 & 1,890 & 1,890 & 1,890 \\
\hline
\end{tabular}

Note: Table IV presents regression results on the timeliness of loss reporting. Regression (1) and (2) relate to profit before taxes as dependent variable while Regression (3) and (4) relate to profit after taxes. Estimates of the base model (3) are reported in column 1 and 3, while estimates of the full model (4) are reported in column 2 and 4 . With respect to the variable names, $D(\Delta \mathrm{NI})_{t-1}$ is a dummy variable equal to one if the preceding year's net income change is negative. $\Delta N I_{t-1}$ is the change in preceding year's net income and $D(\Delta \mathrm{NI})_{t-1} \times \Delta \mathrm{NI}_{t-1}$ is the interaction effect between both. Highperc is a dummy variable, taking the value of one if the PE investor owns more than the predefined cut-off point (40\%) of the outstanding share capital. Higperc is interacted with each of the previously described variables, both separately and combined, to disentangle the timeliness of loss reporting for firms with high versus low equity stakes and with positive versus negative earnings changes in preceding years. ${ }^{* * * *}$ statistically significant at the $1 \%$ confidence level, ${ }^{* *}$ at the $5 \%$ level and ${ }^{*}$ at the $10 \%$ level.

in turn affects the publicly observed financial reporting quality.

Our study has some limitations. First, we focus on the reporting quality of Belgian PE backed companies. Belgium has a bank-centered financial system; therefore, the results may not be transferable to economies with a more equitycentered financial system such as the UK or the US (Black and Gilson, 1998). However, we chose the Belgian context as it is one of the rare settings where accounting information of unquoted companies is publicly available for a large set of unlisted firms. Because of the lack of data on private firms in an international setting, these firms have typically been neglected in the international accounting literature. A disadvantage of our dataset, however, is the lack of specific data like board composition or voting rights, preventing us from undertaking more fine-grained analyses. Second, we treated all PE investors equally and only distinguished them with respect to their equity stake. However, recent research emphasizes that not all $\mathrm{PE}$ is the same. The impact of a PE investor may depend on its experience or portfolio strategy. Further, Leleux and Surlemont (2003) suggest that different types of PE investors typically have different investment horizons, investment goals and incentives, which potentially affect their involvement in their portfolio firms. Bank-related and government-related PE firms are more prominent in Belgium than in other European countries. These two types of investors are typically assumed to be less actively involved with their portfolio companies (Leleux and Surlemont, 2003). The fact that we nevertheless find significant effects, despite their potentially lower involvement on average, enhances the strength of the findings. Due to data limitations, we were not able to take differences between types of PE investors into account and leave this for future research. 
Yet another route for further research is to distinguish between various types of shareholders (Anderson and Reeb, 2003) in studying the associated effect on the quality of accounting information. In the present study, we only investigated the impact of a specific ownership type (PE investors) on the quality of accounting information, without taking other types of shareholders into account. In most firms in our sample, the entrepreneurs were the only other type of shareholders, next to the PE investors. Some firms have other shareholders, however, that may also impact the quality of the accounting information of the portfolio firm. Distinguishing between having business angels or corporate investors as shareholders compared to $\mathrm{PE}$ investors may further enhance our understanding of monitoring efforts of different types of shareholders and their effects on the portfolio company. Further along this route, it might also be interesting to distinguish between first, second or third generation family firms and see how transitions between generations might impact accounting information.

Finally, a more direct measurement of the monitoring effort of PE firms and its impact on the reporting quality of their portfolio companies might yield additional insights. We only studied one of the outcomes of their monitoring efforts, namely the quality of financial accounts. It may well be, however, that the monitoring efforts of the PE investors have additional positive outcomes. Future studies could examine the direct impact of specific PE corporate governance structures and monitoring actions on the professionalization of internal accounting and control systems in portfolio companies.

\section{Notes}

1 We define "private equity" as the provision of (quasi) equity to unquoted companies by professional intermediaries. Venture capital provided to early stage companies is thus a subset of private equity as defined here.

2 In Belgium - the institutional setting of this study both private as well as publicly listed firms have a legal obligation to publicly report their yearly financial statements. In the US, by contrast, financial reporting requirements depend solely on a firm's listing status. The availability of financial statement data of private firms provides the opportunity to study financial reporting characteristics of PE backed firms even before they are publicly listed. More details on the institutional setting and financial reporting requirements are provided in Section 3 on data description and sample composition.

3 In a related paper (Beuselinck et al., 2004), we show (amongst others) that the quality of the accounting information of PE backed companies is higher than that of nonPE backed companies, irrespective of the equity stake of the $\mathrm{PE}$ investor. Hence, the quality of the accounting information of PE backed companies where the investors hold large equity stakes is still higher on average than that of non PE backed companies.

4 Note that because of the private character of our sample firms, we do not have information on the board composition nor on voting power rights in our sample firms. We hence assume that equity ownership captures this information sufficiently well.

5 Hellmann and Puri (2002) document that the effect that $\mathrm{PE}$ investors have on their portfolio companies is strongest when firms are not publicly listed. This dataset provides an excellent opportunity to analyze the under-explored impact that PE governance has on the financial reporting behavior of their unlisted portfolio firms. Moreover, this dataset suffers less from survivorship bias than US studies on preIPO PE backed firms.

6 Note that our results are unaffected when we include only firms that are more than three or five years old. However, restricting the firm's age too much substantially reduces the number of testable observations. As a result, we decide to incorporate as much information as possible in our study by setting the minimum age equal to two years.

7 Remark that, if $\beta_{7}>0$ (resp. $<0$ ), then Highperc firms recognize losses less timely (resp. more timely) than gains, compared to firms in which PE investors hold low equity stakes.

8 To the extent that proportional equity ownership is an entrepreneurial choice, this potentially raises the concern of endogeneity bias in our results. To overcome problems of endogeneity, we estimated PE equity ownership (HighLow) choice simultaneously with the accruals regressions. In unreported tests, we ran two-stage Heckman regressions including the natural logarithm of total assets, the year-onyear growth in total assets, the long-term leverage, the quick ratio and return on assets as explanatory variables in the first stage (selection model). Results of the second stage regressions then incorporate the initial regression variables plus the coefficient on the inverse Mills ratio (IMR). Although coefficients on the IMR are significant, the coefficients of interest remain stable comforting the idea that endogeneity bias, if present in any form, is not distorting our results and interpretations.

9 Note that Belgian financial reports are used as input for calculating tax figures too. Taxable income is computed from financial reports taking a number of specific adjustments into account (e.g. depreciation adjustments, carry-forward of losses, dividend adjustments, exclusion of specific costs). Because of this link between tax and financial accounting, we study both pre-tax and after tax income levels, as it is unclear what the potential confounding effect of taxes is on the measures for timeliness of loss reporting. 
Moreover, the distinction between pre-tax and after tax income is potentially important for firm-years where deferred taxes result in negative profits after taxes while pre-tax profits are positive.

10 Consistent with the potential concern of endogeneity bias in our findings, we ran two-stage Heckman tests in the same form as in the accruals regressions, yielding similar results as in the tests reported above.

\section{References}

Aghion, P. and P. Bolton, 1992, 'An Incomplete Contracts Approach to Financial Contracting', Review of Economic Studies 59(3), 473-494.

Anderson, R. and D. Reeb, 2003, 'Founding Family Ownership and Firm Performance: Evidence from the S\&P500', The Journal of Finance 58(3), 1301-1328.

Armstrong, C., A. Davila and G. Foster, 2006, 'Venture-backed Private Equity Valuation And Financial Statement Information', Review of Accounting Studies 11, 119-154.

Baeyens K. and S. Manigart, 2005, 'Follow-on financing of venture capital backed companies: The choice between equity, debt, existing and new investors' Working Paper, Ghent University.

Ball, R. and L. Shivakumar, 2005, 'Earnings Quality in UK Private Firms: Comparative Loss Recognition Timeliness', Journal of Accounting and Economics 39, 83-128.

Beuselinck C., M. Deloof and S. Manigart, 2004, 'Private Equity and Earnings Quality' Working Paper, Ghent University.

Beuselinck C., S. Manigart and T. Van Cauwenberge, 2006, Private Equity Investors, Corporate Governance and Professionalization, 'Starting up and Growing New Ventures: The Role of the Financial Community', edited by Bart Clarysse and Juan Roure, Edward Elger Publishing.

Bharat S., J. Sunder and S. Sunder, 2004, 'Accounting Quality and Debt Contracting', Working Paper, University of Michigan.

Black, B. and R. Gilson, 1998, 'Venture Capital and the Structure Of Capital Markets: Banks Versus Stock Markets', Journal of Financial Economics 47(3), 243-277.

Botazzi L., M. da Rin and T. Hellmann, 2004, 'Active Financial Intermediation: Evidence on the Role of Organizational Specialization and Human Capital' Finance Working Paper 49/2004, European Corporate Governance Institute.

Brander, J., W. Antweiler and R. Amit, 2002, 'Venture Capital Syndication: Improved Venture Selection Versus Value Added Hypothesis', Journal of Economics and Management Strategy 11(3), 423-452.

Cornelli, F. and O. Yosha, 2003, 'Stage Financing and the Role of Convertible Debt', Review of Economic Studies 70(1), 132 .

Cowling, M., 2003, 'Productivity and Corporate Governance in Smaller Firms', Small Business Economics 20, 335-344.
Davila, A. and G. Foster, 2005, 'Management Accounting Systems Adoption Decisions: Evidence And Performance Implications from Early-Stage/Startup Companies', Accounting Review 80(4), 1039-1068.

Dechow, P., 1994, 'Accounting Earnings and Cash Flows as Measures of Firm Performance: The Role of Accounting Accruals', Journal of Accounting and Economics 18, 3-42.

EVCA (European Venture Capital and Private Equity Ass.), Book of Guidelines, 159 pages.

Francis, J., R. LaFond, P. Olsson and K. Schipper, 2005, 'Cost of Capital and Earnings Attributes', Accounting Review 79(4), 967-1010.

Gompers, P. and J. Lerner, 1999, The venture capital cycle, Cambridge Massachusetts: The MIT Press.

Hand, J., 2005, 'The Value Relevance of Financial Statements in the Venture Capital Market', Accounting Review 80(2), 613-648.

Hellmann, T. and M. Puri, 2002, 'Venture Capital and the Professionalization of Start-Up Firms: Empirical Evidence', Journal of Finance 57, 169-197.

Jensen, M. and W. Meckling, 1976, 'Theory of the Firm: Managerial Behavior, Agency Costs and Ownership Structure', Journal of Financial Economics 3(4), 305-360.

Kaplan, S. and P. Strömberg, 2001, 'Venture Capitalists as Principals: Contracting, Screening and Monitoring', American Economic Review 91(2), 426-431.

Kaplan S. and Strömberg P. (2004) 'Financial contracting meets the real world: An empirical analysis of venture capital contracts', Review of Economic Studies: 1-35.

Katz S., 2006, 'Earnings management and conservatism in the transition between private and public ownership: the role of private equity sponsors', Working Paper Columbia University, $60 \mathrm{p}$.

Leleux, B. and B. Surlemont, 2003, 'Public Versus Private Venture Capital: Seeding Versus Crowding Out? A PanEuropean Analysis', Journal of Business Venturing 18, 81104.

Kortum, S. and J. Lerner, 2000, 'Assessing the Contribution of Venture Capital to Innovation', RAND Journal of Economics 31, 647-692.

Manigart, S. and H. Sapienza, 1999, 'Venture capital and growth', in D. L. H. Sexton Landström (eds.), The Blackwell Handbook of Entrepreneurship, Oxford (UK): Blackwell Publishers, 240-258.

Mitchell, F., G. C. Reid and N. G. Terry, 1995, 'Post Investment Demand for Accounting Information by Venture Capitalists', Accounting and Business Research 25(99), 186196.

Sapienza, H. and A. Korsgaard, 1996, 'Procedural Justice in Entrepreneur-Investor Relations', Academy of Management Journal 39(3), 544-574.

Sapienza, H., S. Manigart and W. Vermeir, 1996, 'Venture Capitalist Governance and Value Added in Four Countries', Journal of Business Venturing 11(6), 439-469.

Watts, R., 2003, 'Conservatism in Accounting: Part 1', Accounting Horizons 17, 207-221. 